\title{
Triparental origin of triploid onion, Allium $\times$ cornutum (Clementi ex Visiani, 1842), as evidenced by molecular, phylogenetic and cytogenetic analyses
}

Željana Fredotović ${ }^{1}$, Ivica Šamanić ${ }^{1}$, Hanna Weiss-Schneeweiss ${ }^{2}$, Juraj Kamenjarin', Tae-Soo Jang ${ }^{2}$ and Jasna Puizina ${ }^{1 *}$

\begin{abstract}
Background: Reconstruction of the parental origins of cultivated plants from wild relatives, especially after long periods of domestication, is not a trivial task. However, recent advances in molecular phylogenetics, among other approaches, have proved to be very informative in analyses of the origin and evolution of polyploid genomes. An established minor garden crop, triploid onion Allium $\times$ cornutum (Clementi ex Visiani, 1842) $(2 n=3 x=24)$, is widespread in southeastern Asia and Europe. Our previous cytogenetic analyses confirmed its highly heterozygous karyotype and indicated its possible complex triparental genome origin. Allium cepa L. and Allium roylei Stearn were suggested as two putative parental species of $A$. $\times$ cornutum, whereas the third parental species remained hitherto unknown.

Results: Here we report the phylogenetic analyses of the internal transcribed spacers ITS1-5.8S-ITS2 of 35S rDNA and the non-transcribed spacer (NTS) region of 5 S rDNA of A. $\times$ cornutum and its relatives of the section Cepa. Both ITS and NTS sequence data revealed intra-individual variation in triploid onion, and these data clustered into the three main clades, each with high sequence homology to one of three other species of section Cepa: A. cepa, A. roylei, and unexpectedly, the wild Asian species Allium pskemense B. Fedtsh. Allium pskemense is therefore inferred to be the third, so far unknown, putative parental species of triploid onion Allium $\times$ cornutum. The $35 \mathrm{~S}$ and $5 \mathrm{~S}$ rRNA genes were found to be localised on somatic chromosomes of $A$. $\times$ cornutum and its putative parental species by double fluorescent in situ hybridisation (FISH). The localisation of 35S and 5S rDNA in A. $\times$ cornutum chromosomes corresponded to their respective positions in the three putative parental species, A. cepa, A. pskemense, and A. roylei. GISH (genomic in situ hybridisation) using DNA of the three putative parental diploids corroborated the results of the phylogenetic study.
\end{abstract}

Conclusions: The combined molecular, phylogenetic and cytogenetic data obtained in this study provided evidence for a unique triparental origin of triploid onion $A$. $\times$ cornutum with three putative parental species, $A$. cepa, A. pskemense, and A. roylei.

Keywords: Allium × cornutum, Allium cepa, Allium roylei, Allium pskemense, Triparental hybrid, Triploid, Fluorescence in situ hybridisation (FISH), ITS1-5.8S-ITS2, 5 rDNA non-transcribed spacer (NTS), Genomic in situ hybridisation (GISH)

\footnotetext{
*Correspondence: puizina@pmfst.hr

'Department of Biology, University of Split, Faculty of Science, Teslina 12, 21000 Split, Croatia

Full list of author information is available at the end of the article
} 


\section{Background}

Polyploidy and hybridisation are regarded as important processes accompanying and contributing to plant diversification and speciation. Allopolyploidy, which involves both of these processes, is regarded as a particularly important driving force of plant evolution. Inferring the parental origin of allopolyploids is not a trivial task, particularly after long periods of hybrid domestication. Recent technological advances and the common use of DNA sequence data for phylogenetic reconstructions revolutionised this field and enabled the identification of the parental taxa of many allopolyploids [1]. Most of the established allopolyploids are of biparental origin. There are very few reported cases of triparental polyploids, although well-known examples include common wheat, Triticum aestivum, which is allohexaploid and of triparental origin [2] and tetraploid Damask roses [3]. Most of the known allopolyploids are established on even-ploidy levels with very few consistently odd-ploidy level taxa persisting in nature (e.g., pentaploid Rosa canina) $[4,5])$.

Triparental odd-ploidy plant allopolyploids have rarely been found. Previous analyses of established and vegetatively propagating triploid Allium $\times$ cornutum (Clementi ex Visiani, 1842) suggested that it is one of the rare cases of allotriploid of triparental origin, and two parental taxa were suggested based on cytogenetic analyses of chromosome complements using GISH (genomic in situ hybridisation) [6]. The third parental taxon remained unknown. Triploid onion Allium $\times$ cornutum is traditionally cultivated in southern and coastal Croatia under the name 'Ljutika' (meaning 'shallot' in Croatian), and it is very popular as a spice and condiment due to its tasty bulbs and leaves [7]. Similar triploid onions are cultivated as garden crops in southeastern Asia, Europe, and other parts of the world [8-12]. Triploid onion was first described as Allium cepa L. var. viviparum (Metzg). Alef. $[9,13,14]$; however, Friesen \& Klaas [11] suggested that this name is connected with the other viviparous onion A. $\times$ proliferum, and they proposed the use of the name Allium cornutum Clementi ex Visiani [15], which is the only name that is unambiguously connected with triploid onion $[10,16]$. However, taking into account its hybrid origin, the name was modified to Allium $\times$ cornutum [11]. This name was first used by Visiani [15] for a Dalmatian bulbiferous taxon that was observed for the first time on rocks in Dubrovnik [16].

In contrast to most flowering alliums in which the leaves start to senesce during flowering, triploid onions are perennials; their leaves remain green throughout the entire year. The plants are sterile and propagate vegetatively by underground bulbs and bulbils formed from the inflorescence. Phenotypically, triploid onions closely resemble A. cepa, and it is sometimes difficult to distinguish between these two types before the development of inflorescences. Inflorescences of triploid onion are composed of fewer and slightly larger flowers than A. cepa inflorescences. During inflorescence maturation, small reproductive bulbils are formed, and the flowers gradually wilt. Mature inflorescence may contain 20-30 small reproductive bulbils. Other reliable characters that allow the distinction between triploid shallot and $A$. сеpa are the morphological features of the underground bulbs, which are elongated and pear-shaped in triploid onions; $10-20$ or more individual bulbs usually grow together. The triploid onion leaves are intermediate in shape between semicircular and round, and the stalk that bears the inflorescence is only slightly flattened at the bottom, whereas that of $A$. сеpa is inflated at the base [17].

The karyotype of $A . \times$ cornutum consists of $2 n=3 x=24$ chromosomes $[8,9]$. The homology among the chromosomes is weak and occasional, and it is very difficult, if not impossible, to identify homologous chromosomes [6]. The most common meiotic chromosome associations of $A . \times$ cornutum are heterotrivalents, which suggests at least partial homology of the three genomes [14]. Additionally, the frequent occurrence of complex multivalents was observed, suggesting that the triploid karyotype might be due to translocations and other chromosomal rearrangements during evolution [14]. Mapping of the constitutive heterochromatin in $A . \times$ cornutum chromosomes by Giemsa C-banding demonstrated its hybrid genome structure with only one set of eight chromosomes shown to carry the heterochromatic markers typical of A. cepa [9]. Previously, triploid viviparous onions were speculated to be either of an allotriploid (AAB) [8] or segmental allotriploid (AA'A") origin [18]. Several independent molecular studies pointed to Allium cepa as one of putative parental species of $A$. $\times$ cornutum (RFLP analysis of the chloroplast DNA and nuclear rDNA [19-21], isozyme analysis [10], and analysis of RAPD molecular markers [12]).

To determine the $A$. $\times$ cornutum origin, genomic in situ hybridisation (GISH) was applied [6,11]. Friesen \& Klaas [11] confirmed $A$. cepa as a parental species of the triploid onion and concluded that the majority of DNA and chromosomes of $A . \times$ cornutum originated from A. cepa. Puizina et al. [6] showed that the genomic DNA of A. cepa and $A$. roylei each only or predominantly labelled only one chromosome set (eight chromosomes with genomic DNA of C - A. cepa and eight with $\mathrm{R}-\mathrm{A}$. roylei). The remaining chromosomes of the triploid karyotype were not labelled (or only partially and weakly labelled) by these two genomic probes. These GISH results provided the first indication that triploid onion might be of complex triparental origin.

Further progress in the identification of the parental species of $A . \times$ cornutum, an 'enigmatic plant' [12], was hampered by the lack of information on the phylogenetic relationships between common onion and its wild relatives 
(section Cepa of genus Allium). More recently, ITS sequences (internal transcribed spacers 1 and 2 of the $18 \mathrm{~S}-5.8 \mathrm{~S}-26 \mathrm{~S}$ rDNA) of a large number of common onion relatives originating from Central Asia were deposited in GenBank [22-27] together with the sequences of the NTS (non-transcribed spacer) of 5S rDNA $[28,29]$.

ITS sequences have frequently been used as a firstchoice marker for inferring the phylogenetic relationships between various wild plant groups and particularly for inferring the origins of diploid and polyploid hybrids (e.g., [30-41]). ITS 1 and 2 are parts of the 18S-5.8S-26S nuclear ribosomal DNA, which is present in each eukaryotic genome in high copy number as tandem repeats in one to many loci per haploid genome [42,43]. rDNA units are prone to homogenisation via unequal crossing over and/or gene conversion [29,42]. Parental rDNA copies in hybrid organisms might evolve in various ways: (1) two parental rDNA types can potentially be retained, evolve independently, and provide direct evidence for historical hybridisation with or without polyploidisation (diploid homoploid hybrids vs. allopolyploids); (2) only one parental rDNA type might be retained in the genome of a hybrid, which typically can be achieved either by the conversion of all rDNA types towards one parental genome rDNA, or alternatively, rDNA of one parental genome might be removed from the hybrid genome; (3) hybrids might evolve new types of rDNA units that might (or might not) represent combinations of different parental rDNA units (reviewed in [44,45]).

Another subfamily of rRNA genes encompasses $5 \mathrm{~S}$ rDNA repeats that are arranged in long tandem arrays in one to several loci in the genome. The 5S rDNA unit consists of a coding region (gene) that is approximately 120 bp in length and a non-transcribed spacer (NTSs), which in plants varies in length and base composition from approximately 100 to more than 700 bp $[45,46]$. The coding regions of 5S RNA are highly conserved, whereas NTS evolves much more rapidly. A high rate of base substitution of NTS in some plant groups qualifies this region as highly informative for molecular phylogenetic analyses and often aids in the identification of parental taxa of diploid and polyploid hybrids [1,46,47]. 5S rDNA does not undergo homogenisation, and unless physically deleted from chromosomes, all types of parental repeats can be detected in hybrids $[1,36,37,48]$. A lack of efficient homogenisation leads to considerable sequence heterogeneity among $5 \mathrm{~S}$ rDNA spacer regions within the individual arrays, which has been reported in several plant groups [1,49-51].

In this paper, we infer the parental origin of allotriploid Allium $\times$ cornutum using molecular phylogenetic analyses of internal transcribed spacers (ITS1-5.8S-ITS2) of 35S rDNA and the non-transcribed spacer (NTS) of the $5 \mathrm{~S}$ rDNA. The positions of these two classes of ribosomal genes have also been established in the somatic chromosomes of $A . \times$ cornutum, and the putative parental species were inferred from phylogenetic analyses (A. pskemense, A. roylei, and A. серa). The triparental origin of $A . \times$ cornutum was confirmed using the genomic in situ hybridisation (GISH) technique. The newly obtained data are discussed in light of previously published data on genome origin, structure, and evolution of the triploid onion A. × cornutum.

\section{Results}

\section{Molecular phylogenetic analysis of ITS and NTS} sequences

The length of the ITS1-5.8S-ITS2 region in the four analysed $A$. xcornutum individuals (each representing a different population; Table 1) ranged from 627 to 642 bps. The final ITS alignment of 48 sequences (clones) of A. × cornutum had 583 constant characters; 17 were parsimony-uninformative, and 27 were parsimonyinformative. In total, 19 distinct ribotypes were found with the most frequent ribotype (denoted by the GenBank accession number KC783412) represented by 24 clones originating from all four individuals (Table 1). The number of variable characters was 18 in the ITS1, four in the $5.8 \mathrm{~S}$ rRNA gene, and 22 in the ITS2 region (Additional file 1: Figure S1).

The sequences of the ITS regions of $A . \times$ cornutum were aligned to other ITS sequence data for Allium species of section Cepa available in GenBank (see Table 2 for the details). Three distinct clades of ITS1-5.8S-ITS2 sequences were identified within the $A . \times$ cornutum genome (Figure 1a, Additional file 1: Figure S1). Most of the sequences (41 sequences) formed one large clade, which also included ITS sequences of the wild Asian species A. pskemense and has therefore been designated xas clade P ("pskemense"-type). A second clade, containing six ITS sequences of $A . \times$ cornutum, grouped with the sequences of $A$. roylei and has been designated as clade R ("roylei"-type). One sequence of $A$. x cornutum (from an individual from Hvar) showed similarity to A. cepa and $A$. vavilovii sequences, and hence, the whole clade was designated as clade C ("cepa"-type) (Figure 1a). The seven $A . \times$ cornutum ITS sequences consisting of clades $\mathrm{R}$ and $C$ had a clearly distinguishable 13 base (CTGTAAA CATACT) insertion in the ITS2 region, which is shared by both $A$. cepa and A. roylei but absent in A. pskemense (Additional file 1: Figure S1).

The presence of different ITS1-5.8S-ITS2 rDNA repeat types within the $A . \times$ cornutum genome and their genetic similarity to their putative parental species $A$. pskemense, $A$. roylei, and $A$. cepa was confirmed by phylogenetic analysis. The phylogenetic algorithms Maximum-Likelihood (ML) and Bayesian Inference (BI) resulted in nearly the same tree topology. Only the BI tree is shown (Figure 1a), 
Table 1 GenBank accession numbers for the ITS1-5.8S-ITS2 and NTS-5S rRNA sequences of $A . \times$ cornutum obtained in this study

\begin{tabular}{lllll}
\hline ITS1-5.8S-ITS2 & & & \\
\hline KC783412 & Dubrava_8 & Hvar_2 & Kastela_1 & Vis_5 \\
& Dubrava_15 & Hvar_3 & Kastela_2 & Vis_10 \\
& Dubrava_16 & Hvar_4 & Kastela_5 & Vis_11 \\
& Dubrava_18 & & Kastela_8 & Vis_12 \\
& Dubrava_22 & & Kastela_11 & Vis_14 \\
& Dubrava_23 & & Kastela_12 & Vis_19 \\
& & & & Vis_20 \\
& & & Vis_27 \\
& & & Vis_28
\end{tabular}

\begin{tabular}{|c|c|c|c|c|}
\hline KC783413 & Dubrava_14 & & & \\
\hline KC783414 & Dubrava_19 & Hvar_10 & & \\
\hline KC783415 & Dubrava_23 & & Kastela_7 & \\
\hline KC783416 & Dubrava_31 & & Kastela_6 & \\
\hline KC783417 & & Hvar_1 & & \\
\hline KC783418 & & Hvar_8 & & \\
\hline KC783419 & & Hvar_12 & & \\
\hline KC783420 & & Hvar_17 & & \\
\hline KC783421 & & Hvar_18 & & \\
\hline KC783422 & & & & Vis_15 \\
\hline KC783423 & & & & Vis_16 \\
\hline KC783424 & & & & Vis_22 \\
\hline KC783425 & & & & Vis_26 \\
\hline KC783426 & & & & Vis_29 \\
\hline KC783427 & Dubrava_10 & & & \\
\hline \multirow[t]{2}{*}{ KC783428 } & Dubrava_12 & & & \\
\hline & Dubrava_30 & & & \\
\hline \multirow[t]{2}{*}{ KC783429 } & Dubrava_13 & Hvar_20 & & \\
\hline & Dubrava_17 & & & \\
\hline KC783430 & & Hvar_21 & & \\
\hline \multirow[t]{2}{*}{ Total: } & 15 & 11 & 8 & 14 \\
\hline & NTS-5S & & & \\
\hline KC794504 & Dubrava_28 & & & \\
\hline KC794505 & & & & Vis_30 \\
\hline KC794506 & Dubrava_36 & & & \\
\hline KC794507 & & Hvar_23 & & \\
\hline KC794508 & & Hvar_26 & & \\
\hline KC794509 & & Hvar_28 & & \\
\hline KC794510 & Dubrava_26 & & & \\
\hline KC794511 & Dubrava_38 & & & \\
\hline KC794512 & & & & Vis_33 \\
\hline KC794513 & & & & Vis_39 \\
\hline
\end{tabular}

Table 1 GenBank accession numbers for the ITS1-5.8S-ITS2 and NTS-5S rRNA sequences of $A . \times$ cornutum obtained in this study (Continued)

\begin{tabular}{|c|c|c|c|c|}
\hline KC794515 & & & & Vis_38 \\
\hline KC794516 & & & & Vis_40 \\
\hline KC794517 & Dubrava_35 & & & \\
\hline KC794518 & & & & Vis_23 \\
\hline KC794519 & & & & Vis_31 \\
\hline KC794520 & & Hvar_15 & & \\
\hline KC794521 & & Hvar_22 & & \\
\hline KC794522 & & Hvar_13 & & \\
\hline Total: & 6 & 6 & - & 7 \\
\hline
\end{tabular}

which summarises the topology and posterior probabilities (PP) from BI plus bootstrap support (BS) from the ML analysis. All the ITS sequences of $A . \times$ cornutum clustered into the three clades: P, R and C (Figure 1a). The clades $\mathrm{P}$ and $\mathrm{R}$ were both strongly supported by both analyses (clade P: 1.0 PP, 98\% BS; clade R: 0.98 PP, 97\% BS). The clade $\mathrm{C}$ containing a single $A . \times$ cornutum sequence (Hvar 21) and sequences from A. cepa, A. vavilovii and A. asarense was less strongly supported (1.0 PP; 69\% BS).

To analyse the variability of non-transcribed spacer (NTS) of the 5S rRNA genes in A. $\times$ cornutum, 19 clones were obtained from three $A . \times$ cornutum individuals (Table 1). The NTS region showed higher sequence variation than the ITS1 and 2 regions. Nearly all of the cloned sequences were unique. The length of the $5 \mathrm{~S}$ rDNA unit including the non-transcribed spacer (NTS) region ranged from 339 to 346 bps. The conserved 5S rRNA coding region was excluded from further analyses. The NTS region comprised 224-231 characters, of which 148 were constant and 73 were variable (including 53 parsimony uninformative and 20 parsimony-informative characters). In total, 13 positions in the alignment included gaps (Additional file 2: Figure S2).

Phylogenetic analyses of NTS clones of A. × cornutum together with NTS sequences of their potential close relatives retrieved from GenBank (Table 2) supported the grouping of the $A . \times$ cornutum NTS sequences into the three well-supported clades (P, R and C; Figure 1b). The largest clade consisted of 11 sequences and grouped with the NTS sequences of Allium pskemense, A. altaicum and $A . \times$ proliferum (88-92\% similarity), and this clade has been designated as clade $\mathrm{P}$. The second largest clade (R) consisted of five NTS sequences of $A . \times$ cornutum, which grouped with $A$. roylei NTS regions (89\% similarity). The smallest clade $(C)$ consisted of only three NTS sequences of $A . \times$ cornutum, which were $99 \%$ identical to the NTS sequences of $A$. cepa and $A$. vavilovii. The largest clade $\mathrm{P}$, comprising 11 NTS sequences of $A . \times$ cornutum, has been 
Table 2 List of taxa, GenBank accession numbers, and references for the previously published sequences used in this study

\begin{tabular}{|c|c|c|c|c|}
\hline \multirow{3}{*}{ Allium pskemense } & \multicolumn{4}{|c|}{ GenBank accession number (reference) } \\
\hline & \multicolumn{2}{|l|}{ ITS1-5.8S-ITS2 } & \multicolumn{2}{|l|}{ NTS-5S } \\
\hline & AM418380 & (Gurushidze et al. 2007) [22] & JF496621 & (Son et al. 2012) [28] \\
\hline & AM418382 & (Gurushidze et al. 2007) & JF496622 & (Son et al. 2012) \\
\hline & AJ411907 & (Friesen et al. 2006) [23] & & \\
\hline \multirow[t]{2}{*}{ Allium roylei } & AJ411945 & (Friesen et al. 2006) & KC731587 & This study \\
\hline & AM492189 & (Gurushidze et al. 2007) & KC731590 & This study \\
\hline \multirow[t]{3}{*}{ Allium cepa } & FJ664287 & (Hirschegger et al. 2010) [24] & AB056584 & (Shibata and Hizume 2002) [29] \\
\hline & AM418367 & (Gurushidze et al. 2007) & AB056593 & (Shibata and Hizume 2002) \\
\hline & AM418370 & (Gurushidze et al. 2007) & & \\
\hline \multirow[t]{3}{*}{ Allium vavilovii } & AM418383 & (Gurushidze et al. 2007) & JF496618 & (Son et al. 2012) \\
\hline & & & JF496619 & (Son et al. 2012) \\
\hline & & & JF496620 & (Son et al. 2012) \\
\hline Allium cepa var. aggregatum & & & JF496648 & (Son et al. 2012) \\
\hline Allium oschaninii & AM418376 & (Gurushidze et al. 2007) & & \\
\hline Allium praemixtum & AM418379 & (Gurushidze et al. 2007) & & \\
\hline Allium farctum & AM492184 & (Gurushidze et al. 2007) & & \\
\hline Allium asarense & AM418365 & (Gurushidze et al. 2007) & & \\
\hline Allium altaicum & GQ412198 GQ181094 & (Jang et al. unpublished) (Li et al. 2010) [25] & JF496602 & (Son et al. 2012) \\
\hline Allium fistulosum & JF990845 & (Guenaoui et al. 2013) [26] & JF496610 & (Son et al. 2012) \\
\hline Allium $\times$ cepiforme & GU566611 & (Li et al. 2010) & & \\
\hline Allium galanthum & GQ181101 & (Li et al. 2010) & & \\
\hline Allium $x$ proliferum & & & JF496645 & (Son et al. 2012) \\
\hline \multirow[t]{3}{*}{ Allium schoenoprasum } & AY427547 & (Ricroch et .al. 2005) [27] & AB066483 & (Shibata and Hizume 2002) \\
\hline & GQ412234 & Jang et al. unpublished & AB066482 & (Shibata and Hizume 2002) \\
\hline & & & AB066474 & (Shibata and Hizume 2002) \\
\hline Allium maximowiczii & GQ412215 & Jang et al. unpublished & & \\
\hline Allium deltoidefistulosum & GQ412203 & Jang et al. unpublished & & \\
\hline Allium linearifolium & GQ412206 & Jang et al. unpublished & & \\
\hline Allium thunbergii & GQ412255 & Jang et al. unpublished & & \\
\hline Allium condensatum & GQ412201 & Jang et al. unpublished & & \\
\hline
\end{tabular}

The exceptions are the sequences for the NTS-5S genes of A. roylei, which were obtained in the present study.

clearly separated from the NTS sequences of its closest relatives, $A$. altaicum, $A$. xproliferum, and $A$. pskemense (Figure 1b).

\section{Chromosomal localisation of 5S rDNA and 35S rDNA genes and genomic in situ hybridisation}

The number and localisation of $5 \mathrm{~S}$ and $35 \mathrm{~S}$ rDNA loci were analysed in two clones of Allium $\times$ cornutum (Dubrava and Vis) and in three putative parental diploid taxa that were identified in phylogenetic analyses: Allium cepa, A. pskemense and A. roylei. Allium cepa possessed two loci of $35 \mathrm{~S}$ rDNA in two satellite chromosome pairs and two 5S rDNA loci, both localised on the short arm of chromosome 7 (Figure 2a, b). The 35S rDNA loci differed in the intensity (and likely number of repeat copies). A. pskemense possessed one subterminal locus of $35 \mathrm{~S}$ rDNA located on one satellite chromosome pair and at most two loci of 5S rDNA on chromosome 6 (Figure 2c, d). One larger locus of 5S rDNA was located interstitially in the short arm of chromosome 6 and the other, weaker locus was situated in the pericentric region of the long arm of the same chromosome. Two homologous chromosomes carrying $5 \mathrm{~S}$ rDNA exhibited heterozygosity concerning the presence of a small $5 \mathrm{~S}$ rDNA signal in the pericentromeric region of the long chromosome arm (Figure 2c,d). A. roylei possessed a single locus of $35 \mathrm{~S}$ rDNA on a satellite-bearing chromosome pair (Figure 2e, f) and two 5S rDNA loci of similar size in the small 


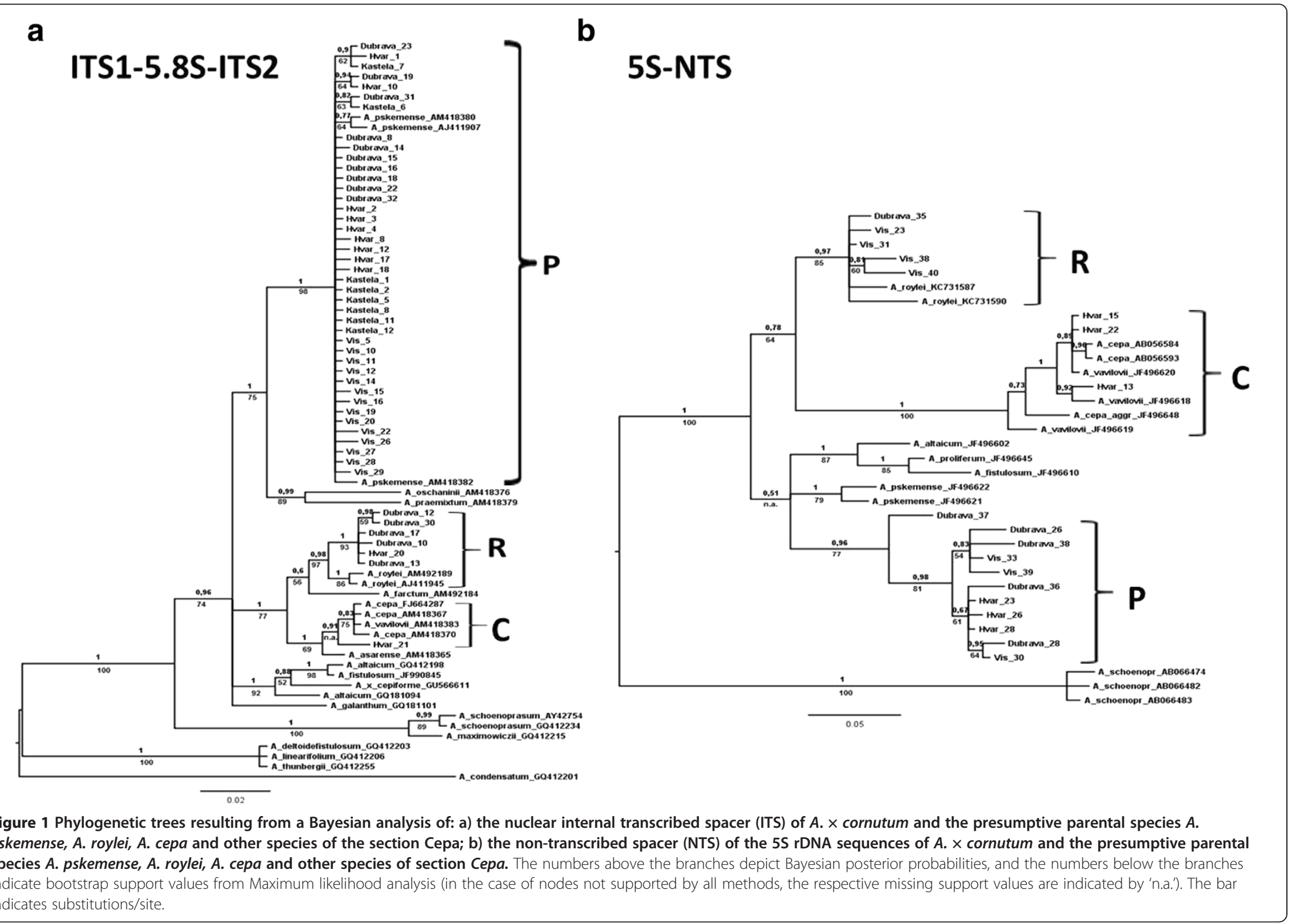



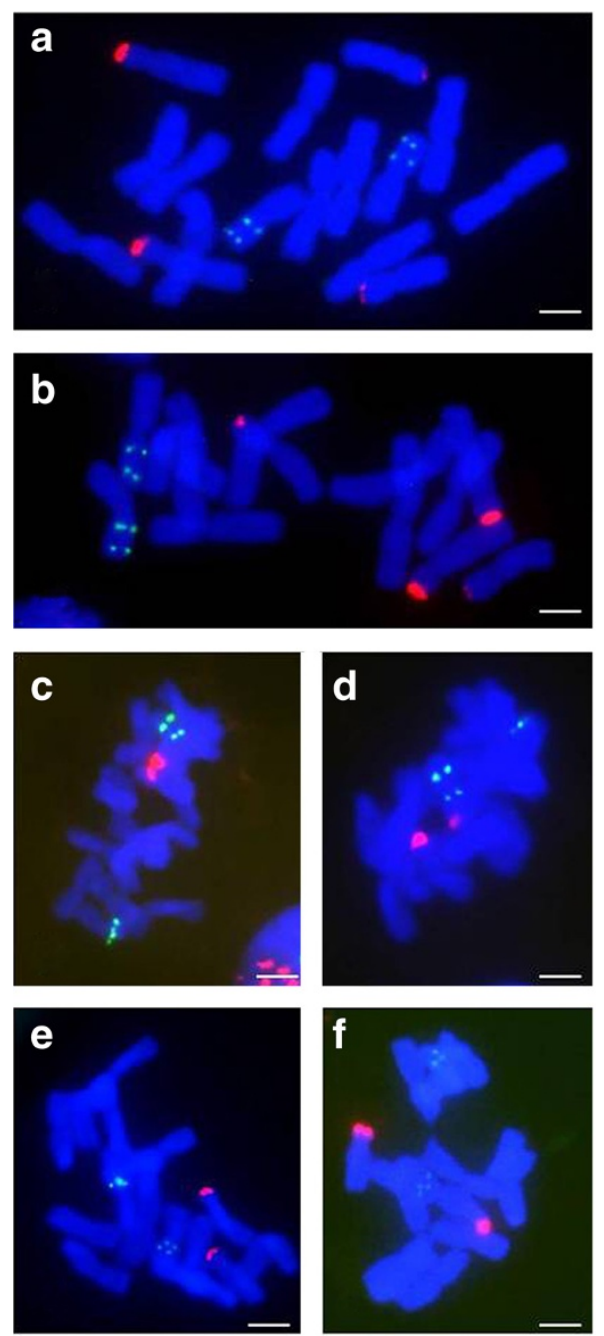
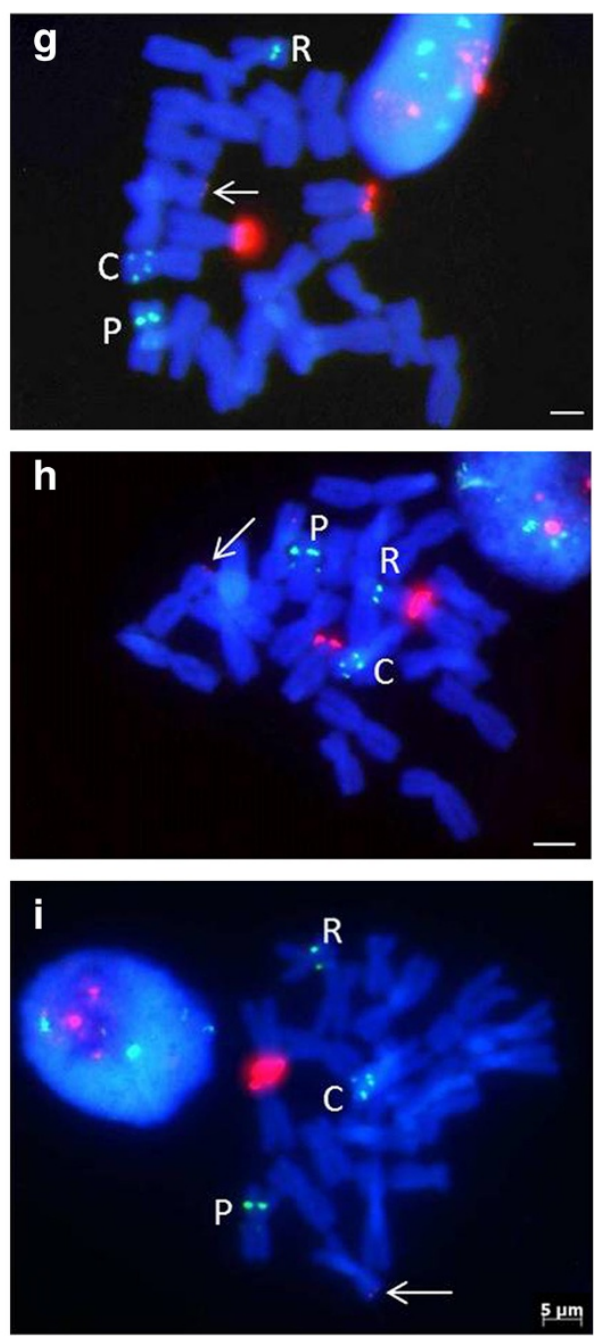

Figure 2 rDNA mapping in the mitotic chromosomes of Allium $\times$ cornutum and the putative parental taxa (5S rDNA red, $35 \mathrm{~S}$ rDNA green). (a, b) Allium cepa; (c, d) A. pskemense; (e, f) A. roylei; (g-i) A. $\times$ cornutum; Arrows in $\mathbf{g}, \mathbf{h}$ and $\mathbf{i}$ indicate the smallest, barely visible $35 \mathrm{~S}$ signal on the medium-sized metacentric chromosome originating from A. cepa. Scale bar $=10 \mu \mathrm{m}$.

metacentric chromosome 7 . One of these $5 \mathrm{~S}$ rDNA loci was localised close to the pericentric region, and the other was localised more internally within the same arm (Figure 2e,f).

In triploid $A$. × cornutum, two major subterminally localised signals of $35 \mathrm{~S}$ rDNA were detected in the short arms of the two subtelocentric satellite chromosomes. A third minor 35S rDNA signal was detected on some spreads and was located in the subtelomeric region of one small sub-metacentric chromosome (white arrows in Figure 2g, h, i). The largest satellite chromosome (resembling the large NOR-bearing chromosome of A. сера) lacked a $35 \mathrm{~S}$ rDNA signal. Each of the three $35 \mathrm{~S}$ rDNA signals differed in intensity and size, with the medium-sized chromosome carrying the strongest signal.
The 5S rRNA genes were detected in three differently sized chromosomes in A. × cornutum (Figure $2 \mathrm{~g}, \mathrm{~h}, \mathrm{i}$ ). The largest chromosome carrying a $5 \mathrm{~S}$ rDNA signal resembled the typical $A$. cepa chromosome with two $5 \mathrm{~S}$ rDNA loci localised within the long arm of chromosome 7. The medium sized chromosome carrying $5 \mathrm{~S}$ rDNA in A. $\times$ cornutum possessed two $5 \mathrm{~S}$ rDNA loci, which differed in size and intensity, with the stronger signal positioned interstitially within the short arm and the weaker signal corresponding to the pericentromeric region of the long chromosome arm. This chromosome bears resemblance to the $5 \mathrm{~S}$ rDNA-bearing $A$. pskemense chromosome. The smallest chromosome carrying $5 \mathrm{~S}$ rDNA in triploid $A l$ lium possessed only one signal in the pericentromeric region of the short chromosome arm (Figure 2g, h, i). This 


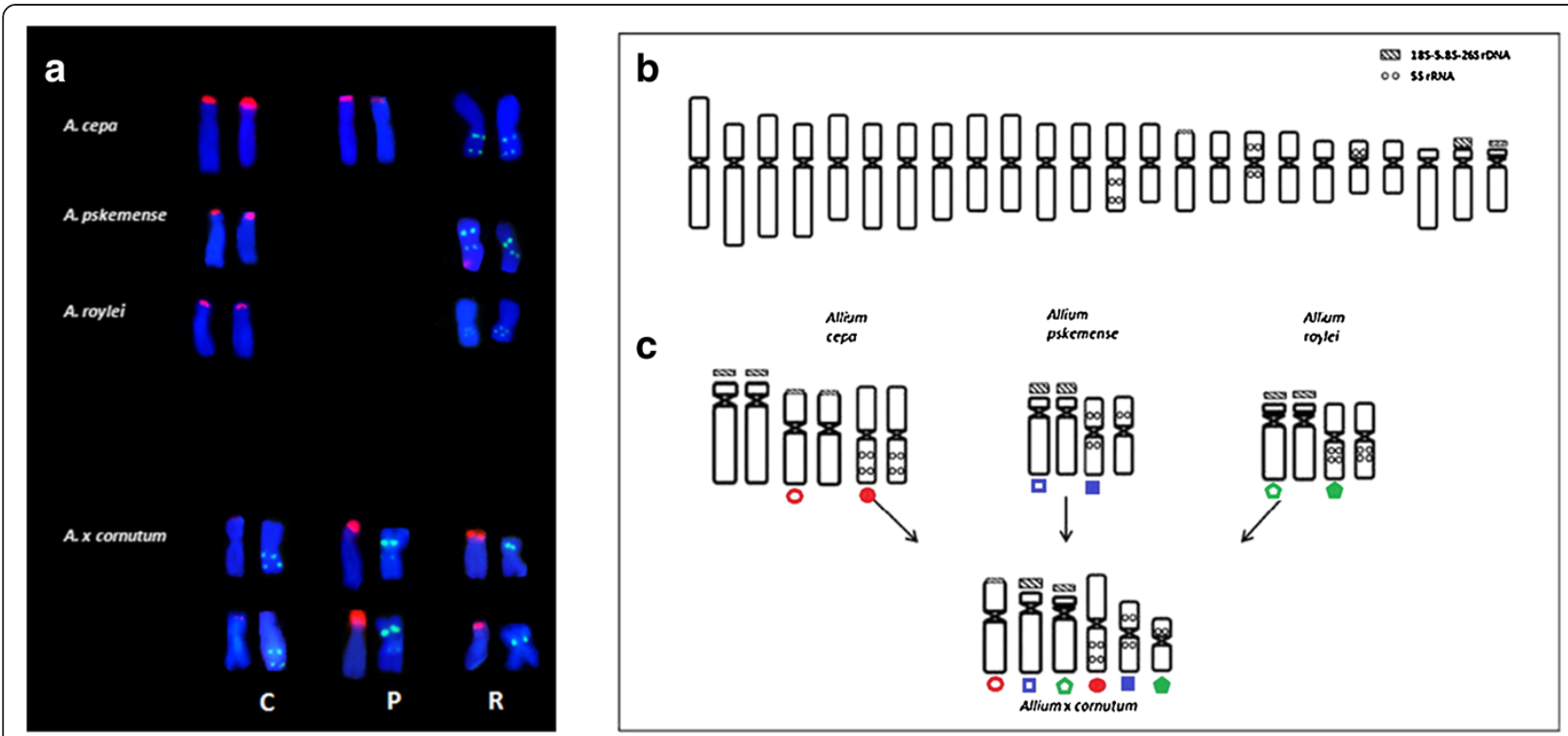

Figure 3 Distribution and origin of rDNA loci in triploid $\boldsymbol{A} . \times$ cornutum. (a) Chromosomes carrying $5 S$ and $35 S$ rDNA in A. $\times$ cornutum and three putative parental taxa; (b) idiogram of A. $\times$ cornutum (modified from Puizina et. al. 1999); (c) origin and localisation of the $5 S$ and 355 rRNA genes in triploid onion. Tri-colour circles, squares and pentagons were used to label the chromosomes that carry $5 S$ and 355 rDNA in the progenitor species and the corresponding chromosomes in the triploid hybrid A. $\times$ cornutum.
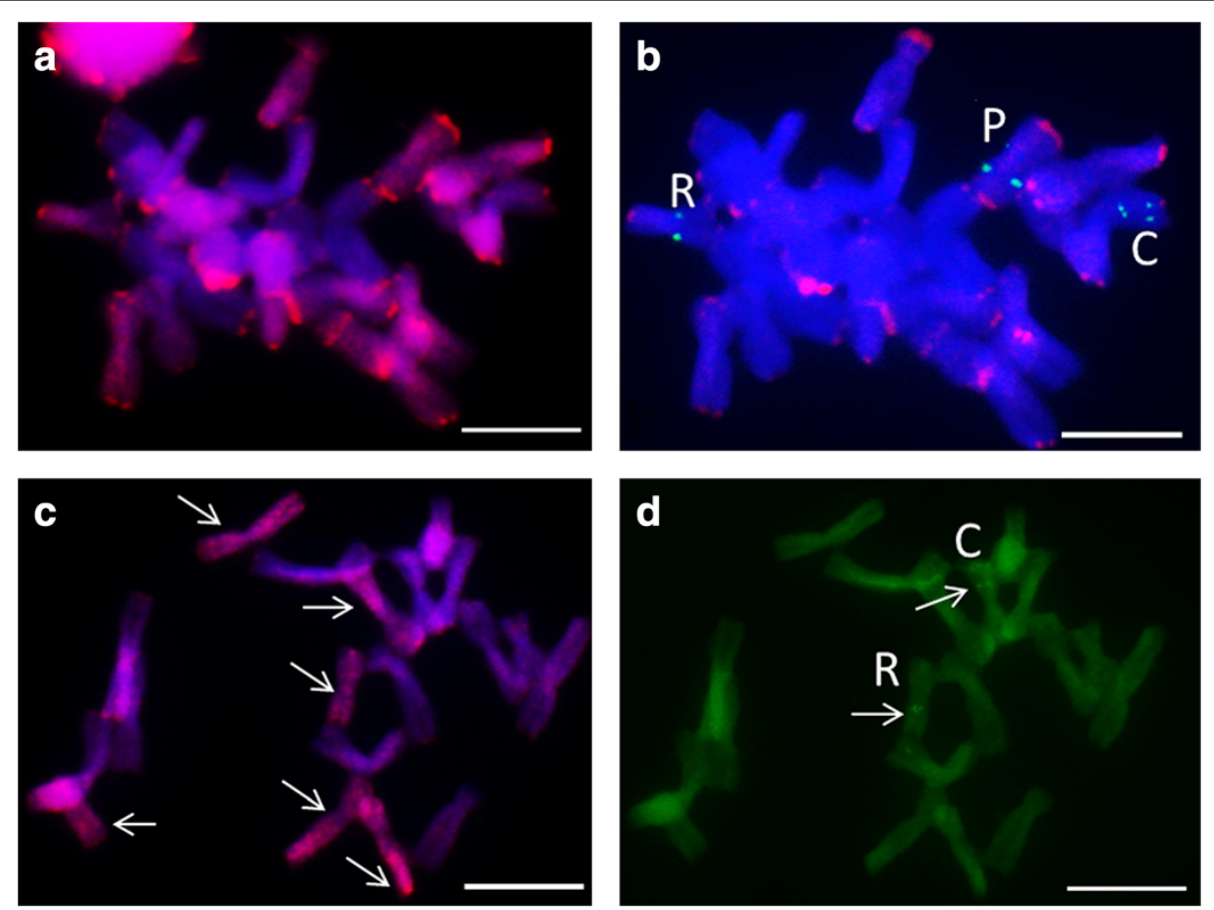

Figure 4 Genomic in situ hybridisation (GISH); a, c) and subsequent 5S rDNA mapping (b, d) to mitotic metaphase chromosomes of Allium $\times$ cornutum. (a) GISH with genomic DNA of A. pskemense (red) and A. cepa as blocking DNA, incomplete metaphase plate; (b) $5 S$ rDNA (green) localisation in the same chromosomal spread (c) GISH with genomic DNA of A. roylei (red) and A. cepa as blocking DNA, incomplete metaphase plate; (d) $5 \mathrm{~S}$ rDNA (green) mapping in the same chromosomal spread. The letters C, R, and P indicate chromosomes carrying the $5 \mathrm{~S}$ signal and belonging to the three different genomes (due to insufficient washing of the genomic probe, red subtelomeric signals (b) remained visible in majority of the chromosomes). Scale bar $=10 \mu \mathrm{m}$. A few of the nuclei (top left and right corners) visible in (a) were lost during reprobing and are not visible in (b). 

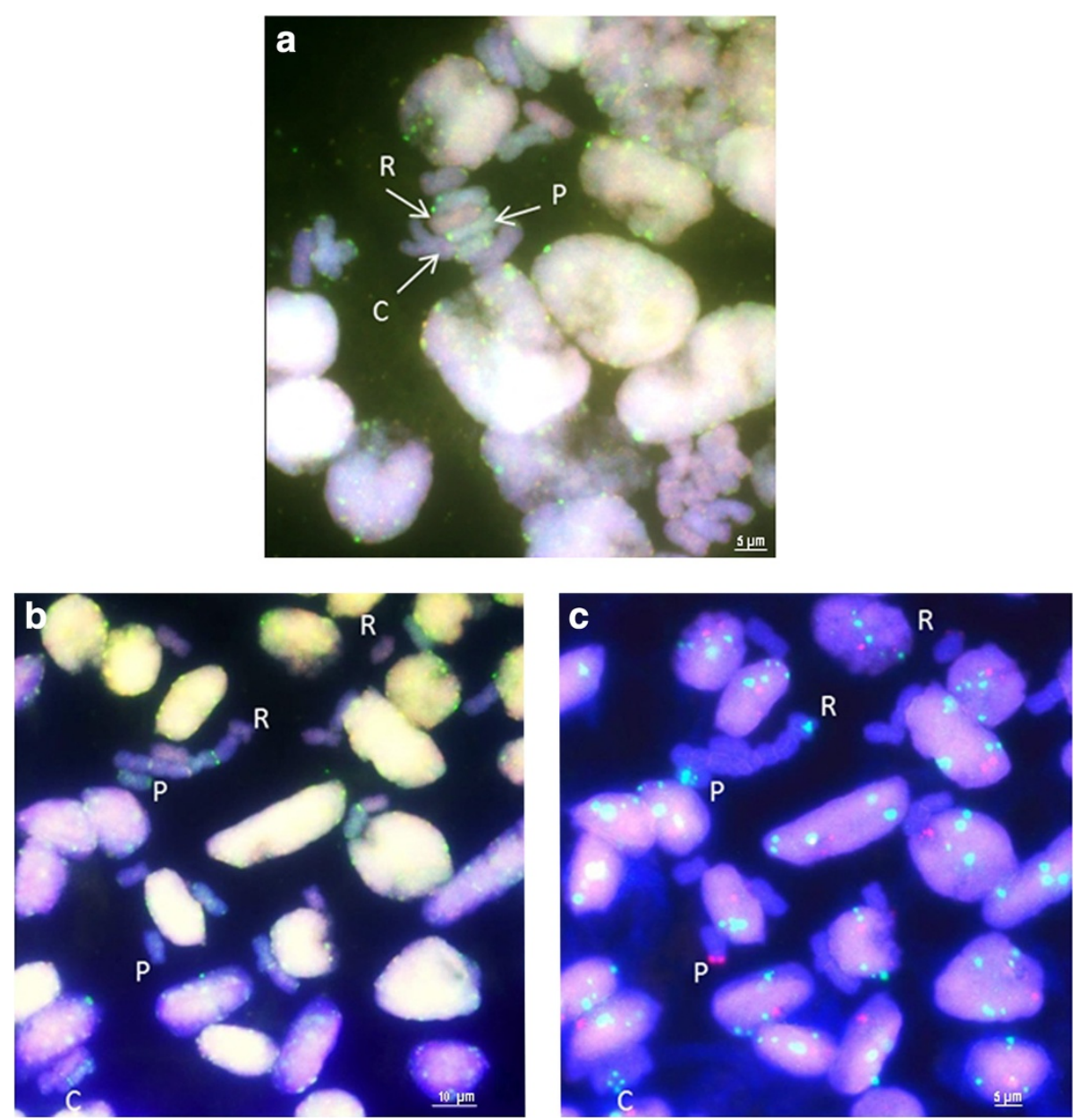

Figure 5 Genomic in situ hybridisation (GISH) in Allium $\times$ cornutum; a, b) and subsequent 5 S rDNA mapping (c) to mitotic metaphase chromosomes of Allium $\times$ cornutum. (a, b) GISH with genomic DNA of A. pskemense (green), A. roylei (red) and A. cepa as blocking DNA (DAPI-blue); (a) Arrows and letters (C, R, and P) indicate the putative parental origins of the three genomes (A. cepa, A. roylei and A. pskemense, respectively); (b, c) The letters $C, R$, and $P$ indicate chromosomes carrying $5 S$ (green) and $35 S$ (red) signals that belong to the three different parental genomes. C genome The $35 \mathrm{~S}$ rDNA-carrying chromosome could not be identified; therefore it is not indicated. One nucleus (top left corner) visible in (b) was lost during reprobing and is not visible in (c).

chromosome might represent a truncated and/or rearranged chromosome 7 of $A$. roylei (Figure 2e, f).

The results of FISH mapping of 5S rDNA supported the inferences of the phylogenetic analyses of the $5 \mathrm{~S}$ and $35 \mathrm{~S}$ rDNA of triparental origin of $A . \times$ cornutum triploids. The three chromosomes carrying 5S rDNA genes in A. $\times$ cornutum likely originated from three different diploid Allium species (Figure 3).

A combination of genomic in situ hybridisation (GISH) and FISH was attempted to identify the genomic origin of $5 \mathrm{~S}$ rDNA-bearing chromosomes (Figures 4a-d; 5b, c). A single chromosome carrying two 5S rDNA loci (designated as $\mathrm{P}$ ) was clearly labelled with $A$. pskemense genomic DNA, in contrast to the two other chromosomes carrying the $5 \mathrm{~S}$ rDNA signals (designated as $\mathrm{R}$ and $\mathrm{C}$ ), which remained unlabelled or were only weakly labelled (Figure 4b). The hybridisation of the genomic DNA of $A$. roylei to the incomplete metaphase plate of $A . \times$ cornutum in the presence of an excess of unlabelled A. сера total genomic DNA as blocking DNA (Figure 4c) allowed the labelling of six chromosomes of the triploid onion, which are marked by arrows. Among the chromosomes labelled with $A$. roylei genomic DNA, one chromosome carrying $5 \mathrm{~S}$ rDNA is indicated (designated as R; Figure $4 \mathrm{~d}$ ). This chromosome corresponds to the smallest 5S rDNA-bearing chromosome, which is likely a truncated A. roylei-originating chromosome (Figure 3). With the aim to simultaneously discriminate between the three genomes of $A . \times$ cornutum (the putative $\mathrm{C}, \mathrm{R}$ and $\mathrm{P}$ genomes), we performed genomic in situ hybridisation with two labelled parental DNA sequences as probes (A. pskemense genomic DNA was labelled in green; $A$. roylei genomic DNA was labelled in red), whereas the genomic DNA of A. cepa remained unlabelled and was used as blocking DNA 
(Figure 5a, b). Eight chromosomes were labelled predominantly with $A$. pskemense genomic DNA (P-genome; green; Figure 5a); furthermore, eight chromosomes hybridised predominantly with $A$. roylei genomic DNA (R-genome; red), and eight chromosomes remained nearly unlabelled (C-genome, blue). The chromosomes have subsequently been reprobed with $35 \mathrm{~S}$ and $5 \mathrm{~S}$ rDNA probes. A comparison of Figure $5 \mathrm{~b}$ and c confirms that the three different $5 \mathrm{~S}$-bearing chromosomes of $A . \times$ cornutum belong to three different parental genomes.

\section{Discussion}

Triparental allopolyploid origin of $A . \times$ cornutum and the identification of its putative parental species

Two contradictory studies have been published concerning the origin of the triploid onion $A . \times$ cornutum $[6,11$; reviewed in 12$]$. The suggested triparental origin of a triploid has been proposed, but only two putative parental taxa were suggested (A. cepa and $A$. roylei), with the third parental taxon remaining unknown (the so-called "X genome"; [6]). The present study provides phylogenetic evidence for a triparental hybrid origin of A. $\times$ cornutum, supported by the mapping of the $5 \mathrm{~S}$ and $35 \mathrm{~S}$ rRNA genes in the chromosomes of putative parental taxa and the hybrid. Additionally, the third putative parental species, the wild Asian species A. pskemense B. Fedtsh., has been identified. These data support the complex hybrid origin of $A$. × cornutum and allow the rejection of previous hypotheses [11], which postulated the origin of $A . \times$ cornutum as a derivative of $A$. cepa. The current study clearly demonstrates that $A . \times$ cornutum contains three types of both ITS and NTS sequences, each grouping with one of three putative parental taxa, Allium pskemense, A. roylei, and A. cepa.

GISH allowed the detection of the three parental genomes in the hybrid, despite some level of crosshybridisation. Using a combination of GISH and FISH, $5 \mathrm{~S}$ and $35 \mathrm{~S}$ rDNA-bearing chromosomes of the hybrid were shown to originate from the respective chromosomes of the putative parents.

\section{ITS sequence variability and 35S rDNA mapping}

The phylogenetic analysis of the ITS region of $A . \times$ cornutum revealed three major ITS types denoted as P, R, and $C$. These types were recovered as separate clades in combined analyses and were shown to bear high sequence similarity to three diploid Allium species/lineages: A. pskemense, A. roylei, and A. cepa/A. vavilovii. A. cepa and $A$. vavilovii are closely related, with $A$. серa being known only as a cultivated taxon; $A$. vavilovii was inferred as its closest wild relative [22].

Concordantly, three $35 \mathrm{~S}$ rDNA loci were detected on three different chromosomes in triploid onion, in agreement with a previous report [52], and could be assigned to the three putative parental genomes. Our previous GISH analysis [6] showed that the medium-sized NOR chromosome carrying the largest 35S rDNA locus did not hybridise either with genomic probes of $A$. серa or of $A$. roylei, thus being assigned to the unidentified $\mathrm{X}$ genome. The current study showed that this locus originates from $A$. pskemense and was the source of the majority of the cloned ITS sequence regions (41 out of 48 ITS clones). The major $35 \mathrm{~S}$ rDNA locus originating from the $A$. cepa genome has either been lost during the evolution of the triploid genome or contains only very few copies that are below the detection limit of FISH. The second (minor) A. cepa locus, which has been detected in the triploid hybrid on the medium-sized submetacentric chromosome, contains a very small copy number and might be in the process of being lost. The single ITS sequence of the C-type (clone Hvar 21) that was recovered from the triploid onion genome likely represents the A. cepa minor $35 \mathrm{~S}$ rDNA locus.

Earlier analyses of the activity of the NOR regions in triploid onion using silver staining indicated that all three $35 \mathrm{~S}$ rDNA loci were active with a maximum of three nucleoli detected in the interphase nuclei of all five Croatian clones of $A . \times$ cornutum [14]. In contrast, Pran, the Indian clone of triploid $A . \times$ cornutum, possessed only a single active NOR on a medium-sized satellite chromosome [14]. Such a result indicates ongoing evolution of the rDNA in triploid onions over the whole species distribution range. Multiple origins of this triploid hybrid taxon are currently excluded based on the unique genome size, isozyme, RAPD and RFLP patterns of Pran, Ljutika and other analysed clones of triploid onion $[6,10,11]$.

\section{NTS sequence variation and 5S rDNA mapping}

The divergence of the NTS sequences in several welldocumented allopolyploid systems proved very useful for the identification of the putative parent species: i.e., Nicotiana tabacum [48], Zingeria [53], Anemone multifida and A. baldensis [47], and Melampodium [1]. The 5S rDNA NTS sequences of $A . \times$ cornutum clustered into the three main clades (C, P, and R), which had high sequence homology to the three putative parental species A. cepa, A. pskemense, and A. roylei, respectively. Whereas the clades $\mathrm{C}$ ( $A$. cepa) and $\mathrm{R}$ (A. roylei) were well supported, the clade $\mathrm{P}$ (A. pskemense) failed to form a single wellsupported clade with its closest relatives, $A$. pskemense, A. altaicum, and $A . \times$ proliferum. This result could have been caused by significant intra-individual variability within the NTS region [28] as well as possible high genetic variation of $5 \mathrm{~S}$ rDNA within $A$. pskemense and its relatives across their wide geographical distribution.

The results of the NTS sequence analysis were largely congruent with the cytogenetic mapping of $5 \mathrm{~S}$ rDNA in A. $\times$ cornutum, and 5S rDNA loci were detected in 
different positions in three chromosomes of different morphology. The two larger 5S rDNA-bearing chromosomes greatly resembled the putative parental chromosomes of A. cepa and A. pskemense. The 5S rDNA-bearing chromosome having 5S rDNA loci distributed in a similar manner as in A. pskemense has also been labelled with $A$. pskemense genomic DNA in a GISH experiment. The smallest $5 \mathrm{~S}$ rDNA-bearing chromosome of $A . \times$ cornutum has been shown to hybridise with genomic DNA of A. roylei ([6]; current study), thus confirming its origin from the $\mathrm{R}$ genome (A. roylei). This chromosome, however, differed from the parental $5 \mathrm{~S}$ rDNA-bearing chromosome of $A$. roylei and possessed only a single $5 \mathrm{~S}$ rDNA locus in the pericentromeric region of the short arm of the chromosome instead of two loci. At least two different scenarios can account for the observed truncation: i) the smallest $5 \mathrm{~S}$ rDNA-bearing chromosome and the entire $\mathrm{R}$ genome could have originated from a diploid ancestor closely related to A. roylei, which is characterised by smaller chromosomes and only a single $5 \mathrm{~S}$ rDNA locus; and ii) chromosomes of $A$. $\times$ cornutum originating from the $\mathrm{R}$ genome have undergone rearrangements after hybridisation and lost one of the $5 \mathrm{~S}$ rDNA signals in the process. Based on our current understanding of genome restructuring after allopolyploidisation and a general trend of diploidisation of both the $5 \mathrm{~S}$ and $35 \mathrm{~S}$ rDNA loci, the second hypothesis is more likely [43,54-57], especially because the sequences of $A . \times$ cornutum in clade " $R$ " are very similar to those of $A$. roy$l e i$. The triploid genome of $A . \times$ cornutum might have been subjected to additional genomic rearrangements such as inter-chromosomal translocation, deletions, and/or inversions.

FISH mapping of 35S and 5S rRNA genes in A. pskemense and $A$. roylei and inferences of the phylogenetic relationships in section Cepa

Although the phylogenetic relationships among 12 species of sections of Cepa have been inferred from analyses of plastid regions and ITS [20,22], the chromosomal positions of $35 \mathrm{~S}$ and $5 \mathrm{~S}$ rDNA have so far been determined for only three species: A. cepa, A. fistulosum and A. altaicum [58-61]. The two 5S rDNA loci in $A$. cepa were located on the longer arm of chromosome 7 (as confirmed by our data), whereas in A. fistulosum a single 5S rDNA locus was detected interstitially in the short arm of chromosome 7. In natural diploid homoploid hybrids of $A$. серa and A. fistulosm, top onions (Allium $\times$ proliferum (Moench) Schrad. and Allium wakegi Araki (both $2 n=16$ ), the two chromosomes carrying the 5S rDNA signals corresponded to the $5 \mathrm{~S}$ rDNA-bearing chromosomes of the parental species [58]. In this study, $35 \mathrm{~S}$ and $5 \mathrm{~S}$ ribosomal genes were mapped for the first time in somatic chromosomes of diploid $A$. pskemense and $A$. roylei. These two species possessed an identical number of 35S rDNA loci but differed in the positions of the $5 \mathrm{~S}$ rDNA loci on chromosome 7 . The localisation of $5 \mathrm{~S}$ rDNA in A. roylei chromosome 7 resembles more closely that of $A$. cepa, whereas $A$. pskemense is more similar to $A$. fistulosum and $A$. altaicum. This finding supports the hypothesis of Son et al. [28] that $A$. pskemense is more closely related to A. fistulosum and A. altaicum. The number and position of the 5S rDNA loci, therefore, proved to be evolutionarily informative in analysing the species of Allium from section Cepa.

\section{Conclusions}

The combined molecular phylogenetic and cytogenetic data obtained in this study provide evidence for a unique triparental origin of triploid onion $A . \times$ cornutum and identified all three putative diploid parental species, $A$. cepa, A. pskemense, and $A$. roylei. These results are in agreement with previously published data $[6,9,14]$ and provide new and stronger evidence for the origin of the distinct and complex odd-ploidy allopolyploid $A . \times$ cornutum. The sequence of events leading to the origin of the triploid onion and its phylogeography cannot yet be elucidated and will be addressed using other molecular approaches.

\section{Methods}

\section{Plant materials and DNA extraction}

Four clones of $A$. $\times$ cornutum (known in Croatia under the name Ljutika) were obtained from local gardens and vineyards at four well-separated localities of the Croatian seaside region (Dubrava and Kaštela) and islands (Vis, Hvar). A. pskemense B. Fedt. (CGN21442) and A. roylei Stearn (CGN20520) seeds were kindly provided by the Centre for Plant Breeding and Reproduction Research, Wageningen, The Netherlands. The commercial cultivar A. cepa cv, 'Holland Yellow' was used to obtain the DNA and chromosome complements of $A$. cepa Genomic DNA was extracted from young leaves using the CTAB method according to Saghai Maaroof et al. [62].

\section{PCR amplification and cloning}

The ITS1-5.8S-ITS2 region of 35S rDNA was amplified by PCR using the universal primers ITS1 and ITS4 and the procedures described by Bezić et al. [63]. The whole coding and non-transcribed spacer (NTS) region of the $5 \mathrm{~S}$ rDNA gene was amplified using the primers and conditions from Weiss-Schneeweiss et al. [57]. The amplified products were visualised and confirmed by $1 \%$ agarose gel electrophoresis, extracted from the gel, ligated into pGEM-T Easy vectors (Promega, Madison, Wisconsin, USA) and cloned into competent JM109 E. coli cells. DNA from individual plasmids carrying inserts was isolated using a Plasmid Mini Kit (Qiagen, Hilden, Germany). Purified plasmid DNA was sent to Macrogen (Seoul, Korea) for sequencing of the inserts. 


\section{Sequence analysis}

The DNA sequences were assembled and prealigned using BioEdit ver. 7.0.5.3 [64]. They were then aligned in ClustalW [65] and implemented in MEGA5 [66], and the alignment was refined manually. The sequences were deposited in GenBank (Table 1). To avoid multiple submissions of identical sequences, we sent only one sequence of each type. To infer the phylogenetic relationships from the newly obtained ITS and NTS sequences of $A . \times$ cornutum and other closely related Allium species, the sequences were subjected to a similarity search against the nonredundant nucleotide sequence database using the NCBI (National Centre for Biotechnology Information) BLASTN network service. Sequence alignments of newly amplified regions and sequences of other related Allium species deposited in GenBank were performed using MEGA5 [66]. Polymorphic and variable sites as well as different haplotypes were generated using DnaSP Ver. 5.10 [67]. A Bayesian analysis was performed with MrBayes 3.1 [68] with 4 chains of $1,000,000$ generations, trees sampled every 100 generations and the burn-in value set to $25 \%$ of the sampled trees. The best-fit substitution model was used as determined by the Akaike Information Criterion [69] as implemented in jModelTest 0.1.1 [70]. A maximum-likelihood analysis using starting trees obtained by neighbour-joining and TBR branch swapping with model parameters was performed using PAUP* $4.0 \mathrm{~b} 10$ [71]. The number of bootstrap replicates was set to 1000 . Phylogenetic trees were displayed in FigTree v1.3.1.

\section{Chromosome preparation, fluorescence in situ hybridisation (FISH) and genomic in situ hybridisation (GISH)}

Chromosomes for FISH and GISH were prepared as described by Puizina et al. [6]. Clone pTa794 contained the complete 410-bp BamHI fragment of the 5S rRNA gene, and the spacer region of wheat [72] was used as the $5 \mathrm{~S}$ rDNA probe. The $2.4 \mathrm{~kb}$ HindIII fragment of the partial 18S rRNA gene and ITS1 from Cucurbita pepo, cloned into pUC19 [73], were used as the $18 \mathrm{~S}$ rDNA probe. The $5 \mathrm{~S}$ rDNA probe was labelled with digoxygenin using a DIG-nick translation kit (Roche Diagnostics, Mannheim, Germany), whereas 18S rDNA was labelled with biotin using a BIO-nick translation kit (Roche Diagnostics, Mannheim, Germany). The genomic DNA ( $1 \mu \mathrm{g} /$ reaction) was labelled with biotin using a BIO-nick translation kit (Roche Diagnostics, Mannheim, Germany) according to the supplier's instructions.

The FISH method followed the procedures outlined in Weiss-Schneeweiss et al. [57,74]. Briefly, the preparations were re-fixed and air dried, and chromosomal DNA was denatured in $70 \%(\mathrm{v} / \mathrm{v})$ deionised formamide in $2 \times \mathrm{SSC}, \mathrm{pH} 7.0$ at $70^{\circ} \mathrm{C}$ for $2 \mathrm{~min}$, dehydrated through an ethanol series and air-dried. The hybridisation mixture containing labelled probes (100-150 ng/slide), 20-100x excess blocking DNA (for GISH) or salmon sperm DNA (for FISH), 50\% formamide, 2x SSC, 10\% dextran sulphate, and $0.15 \%$ sodium dodecyl sulphate (SDS) was denatured at $75^{\circ} \mathrm{C}$ for $10 \mathrm{~min}$. The probe was applied to the slides and incubated at $37^{\circ} \mathrm{C}$ in a humid chamber overnight. Subsequently, the slides were washed for $5 \mathrm{~min}$ in $2 \mathrm{x} \mathrm{SSC}$ at $39^{\circ} \mathrm{C}$, for $5 \mathrm{~min}$ in $0.1 \mathrm{x} \mathrm{SSC}$ at $39^{\circ} \mathrm{C}$, and for $5 \mathrm{~min}$ in $2 \mathrm{x} \mathrm{SSC}+0.2 \%$ Tween 20 at $39^{\circ} \mathrm{C}$. Biotinand digoxygenin-labelled probes were detected using Extravidin-Cy3 $(2.5 \mu \mathrm{g} / \mathrm{mL})$ and anti-digoxygenin-FITC $(5 \mu \mathrm{g} / \mathrm{mL})$, respectively, both in $2 \%$ BSA in $2 \mathrm{xSC}+0.2 \%$ Tween 20 buffer at $37^{\circ} \mathrm{C}$ for $60 \mathrm{~min}$. The slides were subsequently washed twice for $7 \mathrm{~min}$ in $2 \mathrm{xSC}$ at $42^{\circ} \mathrm{C}$ and for $7 \mathrm{~min}$ in $2 \mathrm{x} \mathrm{SSC}+0.2 \%$ Tween 20 at $42^{\circ} \mathrm{C}$. Finally, they were mounted in $20 \mu \mathrm{L}$ of the antifade solution Vectashield containing $0.5 \mu \mathrm{g} / \mathrm{mL}$ DAPI (Vector Laboratories, Burlingame, CA, USA) and stored at $4{ }^{\circ} \mathrm{C}$. The slides were examined with a Zeiss Axioimager M1 epifluorescence microscope with a high-resolution microscopy camera (Carl Zeiss AxioCam MR Rev3) using Axio Vision Rel. 4.7 software (Karl Zeiss, Vienna, Austria). For rDNA localisation, an average of 15-20 metaphase plates were analysed for each species. GISH hybridisation and detection were performed using the same protocols.

\section{Additional files}

Additional file 1: Figure S1. Sequence variation in the nuclear internal transcribed spacer (ITS) from four different plants (clones) of $A$. $\times$ cornutum and its parental species, A. pskemense, A. roylei and A. cepa.

Additional file 2: Figure S2. Sequence variation in the nontranscribed spacer (NTS) of the $5 \mathrm{~S}$ rDNA region in three different plants (clones) of $A . \times$ cornutum.

Competing interests

The authors declare no competing interests.

\section{Authors' contributions}

The experimental design was conceived by JP and HWS. The experiments were performed by ZF, IS, JK, and TY. The data were analysed by JP with assistance from HWS and IS. This paper was written by JP, HWS and ZF. All authors read and approved the final manuscript.

\section{Acknowledgements}

We sincerely thank Prof. Dr. Todd Stuessy for critically reading the manuscript and providing useful suggestions. We thank the Centre for Genetic Resources (CGN, Netherlands) for providing the specimens of A. pskemense and A. roylei used in this study. This work received funding from the Croatian Ministry of Science, Education and Sport through a grant to Jasna Puizina (no. 177-11911196-0829)

\section{Author details}

'Department of Biology, University of Split, Faculty of Science, Teslina 12, 21000 Split, Croatia. ${ }^{2}$ Department of Systematic and Evolutionary Botany, University of Vienna, Rennweg 14, A-1030 Vienna, Austria.

Received: 10 December 2013 Accepted: 8 January 2014

Published: 13 January 2014 


\section{References}

1. Hegarty MJ, Hiscock SJ: Hybrid speciation in plants: new insights from molecular studies. New Phytol 2005, 165:411-423.

2. Zhang P, Li W, Friebe B, Gill BS: Simultaneous painting of three genomes in hexaploid wheat by BAC-FISH. Genome 2004, 47:979-987.

3. Iwataa H, Katob T, Ohnoc S: Triparental origin of damask roses. Gene 2000, 259:53.

4. Lim KY, Werlemark G, Matyasek R, Bringloe JB, Sieber V, El Mokadem H, Meynet J, Hemming J, Leitch AR, Roberts AV: Evolutionary implications of permanent odd polyploidy in the stable sexual, pentaploid of Rosa canina L. Heredity 2005, 94:501-506.

5. Raymond O, Piola F, Sanlaville-Boisson C: Inference of reticulation in outcrossing allopolyploid taxa: caveats, likelihood and perspectives. Trends Ecol Evol 2002, 17:3-6.

6. Puizina J, Javornik B, Bohanec B, Schweizer D, Maluszynska J, Papeš D, Schweizer D: Random amplified polymorphic DNA analysis, genome size, and genomic in situ hybridization of triploid viviparous onions. Genome 1999, 42:1208-1216.

7. Puizina J: Shallots in Croatia - genetics, morphology and nomenclature. Acta Bot Croat 2013, 72(2):387-398.

8. Singh F, Ved Brat S, Khoshoo TN: Natural triploidy in viviparous onions. Cytologia 1967, 32:403-407.

9. Puizina J, Papeš D: Cytogenetical evidence for hybrid structure and origin of diploid and triploid shallots (Allium cepa var. viviparum, Liliaceae) from Dalmatia (Croatia). Plant Syst Evol 1996, 199:203-215.

10. Maass HI: Studies on triploid viviparous onions and their origin. Genet Resour Crop Ev 1997, 44:95-99.

11. Friesen $\mathrm{N}$, Klaas M: Origin of some minor vegetatively propagated Allium crops studied with RAPD and GISH. Genet Resour Crop Ev 1998, 45:511-523.

12. Klaas M, Friesen N: Molecular markers in Allium. In Allium Crop Science: Recent Advances. Edited by Rabinowitch HD, Currah L. Wallingford Oxon OX108DE: CABI Publishing, CAB International; 2001:15-I31.

13. Langer A, Koul AK: Studies on nucleolus and nucleolar chromosomes in angiosperms. VII. Nature of nucleolar chromosome polymorphism in Allium cepa var. viviparum (Metzg.) Alef. Cytologia 1983, 48:323-332.

14. Puizina J, Papeš D: Further cytogenetic analyses of the Croatian triploid shallot "Ljutika" (Allium cepa var. viviparum, Alliaceae) and its comparison with the Indian triploid "Pran". Plant Syst Evol 1997, 208:11-23.

15. Visiani R: Flora Dalmatica 1. Lipsiae: Hofmeister; 1842.

16. Stearn WT: Allium L. In Flora Europea 5. Edited by Tutin TG, Heywood VH. Cambridge: University Press; 1980.

17. Puizina J: Cytogenetic and Molecular Characteristics of Natural Hybrids and Polyploids of Red Onion (Allium cepa L.) PhD. thesis. University of Zagreb, Science Department; 1997.

18. Koul AK, Gohil RN: Further studies on natural triploidy in viviparous onions. Cytology 1971, 36:253-261.

19. Havey MJ: Molecular characterization of the interspecific origin of viviparous onion. J Hered 1991, 82:501-503.

20. Havey MJ: Restriction enzyme analysis of the chloroplast and nuclear $45 \mathrm{~s}$ ribosomal DNA of Allium sections Cepa and Phyllodolon (Alliaceae). Plant Syst Evol 1992, 183:17-31.

21. Havey MJ: A putative donor of S-cytoplasm and its distribution among open-pollinated populations of onion. Theor Appl Genet 1993, 86:128-134.

22. Gurushidze M, Mashayekhi S, Blattner FR, Friesen N, Fritsch RM: Phylogenetic relationship of wild and cultivated species of Allium section Cepa inferred by nuclear rDNA ITS sequence analysis. Plant Syst Evol 2007, 269:259-269.

23. Friesen N, Fritsch RM, Blattner FR: Phylogeny and new infrageneric classification of Allium L.(Alliaceae) based on nuclear ribosomal DNA ITS sequences. Aliso 2006, 22:372-395.

24. Hirschegger P, Jakse J, Trontelj P, Bohanec B: Origins of Allium ampeloprasum 788 horticultural groups and a molecular phylogeny of the section Allium (Allium: 789 Alliaceae). Mol Phylogenet Evol 2010, 54:488-497.

25. Li QQ, Zhou SD, He XY, Yu Y, Zhang YC, Wei XQ: Phylogeny and biogeography of Allium (Amaryllidaceae: Allieae) based on nuclear ribosomal internal transcribed spacer and chloroplast rps 16 sequences, focusing on the inclusion of species endemic to China. Ann Bot 2010, 106(5):709-733.
26. Guenaoui C, Mang S, Figliuolo G, Neffati M: Diversity in Allium smpheloprasum: from small and wild to large and cultivated. Genet Resour Crop Ev 2013, 60(1):97-114.

27. Ricroch A, Yockteng R, Brown SC, Nadot S: Evolution of genome size across some cultivated Allium species. Genome 2005, 48(3):511-520.

28. Son JH, Park KC, Lee Al, Jeon EJ, Kim HH, Kim NS: Sequence variation and comparison of the $5 \mathrm{~S}$ rRNA sequences in Allium species and their chromosomal distribution in four Allium species. J Plant Biol 2012, 55:15-25.

29. Shibata F, Hizume M: Evolution of $5 \mathrm{~S}$ rDNA units and their chromosomal localization in Allium cepa and Allium schoenoprasum revealed by microdissection and FISH. Theor App Genet 2002, 105:167-172.

30. Baldwin BG: Phylogenetic utility of the internal transcribed spacers of nuclear ribosomal DNA in plants: An example from the Compositae. Mol Phylogenet Evol 1992, 1:3-16.

31. Baldwin BG, Sanderson MJ, Porter JM, Wojciechowski MF, Campbell CS, Donoghue MJ: The ITS region of nuclear ribosomal DNA: A valuable source of evidence on angiosperm phylogeny. Ann Missouri Bot Gard 1995, 82:247-277.

32. King RA, Gornall RJ, Preston CD, Croft JM: Molecular confirmation of Potamogeton $\times$ bottnicus (P. pectinatus $\times$ P. vaginatus, Potamogetonaceae) in Britain. Bot J Linn Soc 2001, 135:67-70.

33. Liu B, Brubaker CL, Mergeai G, Cronn RC, Wendel JF: Polyploid formation in cotton is not accompanied by rapid genomic changes. Genome 2001, 44:321-330.

34. Muir G, Fleming CC, Schlötterer C: Three divergent rDNA clusters predate the species divergence in Quercus petraea (Matt.) Liebl. and Quercus robur L. Mol Biol Evol 2001, 18:112-119.

35. Kaplan Z, Fehrer J: Evidence for the hybrid origin of Potamogeton $\mathrm{x}$ cooperi (Potamogetonaceae): traditional morphologybased taxonomy and molecular techniques in concert. Folia Geobot 2004, 39:431-453.

36. Kovarik A, Pires JC, Leitch AR, Lim KY, Sherwood A, Matyasek R, Rocca J, Soltis DE, Soltis PS: Rapid concerted evolution of nuclear ribosomal DNA in two allopolyploids of recent and recurrent origin. Genetics 2005, 169:931-944

37. Kovarik A, Dadejova M, Lim KY, Chase MW, Clarkson JJ, Knapp S, Leitch AR: Evolution of rDNA in Nicotiana allopolyploids: a potential link between rDNA homogenization and epigenetics. Ann Bot 2008, 101:815-823.

38. Lim KY, Matyasek R, Kovarik A, Leitch AR: Parental origin and genome evolution in the allopolyploid Iris versicolor. Ann Bot 2007, 100:219-224.

39. Lim KY, Soltis DE, Soltis PS, Tate J, Matyasek R, Srubarova H, Kovarik A, Pires $J C$, Xiong Z, Leitch AR: Rapid chromosome evolution in recently formed polyploids in Tragopogon (Asteraceae). PLOS ONE 2008, 3(10):e3353.

40. Puizina J, Sviben T, Krajačić-Sokol I, Zoldoš-Pećnik V, Šiljak-Yakovlev S, Papeš $D$, Besendorfer V: Cytogenetic and molecular characterization of Abies alba genome and its relationship with other members of Pinaceae family. Plant Biol 2008, 10:256-267.

41. Ksiazczyk T, Kovarik A, Eber F, Huteau V, Khaitova L, Tesarikova Z, Coriton O, Chevre AM: Immediate unidirectional epigenetic reprogramming of NORs occurs independently of rDNA rearrangements in synthetic and natural forms of a polyploidy species Brassica napus. Chromosoma 2011, 120:557-571.

42. Maluszynska J, Hasterok R, Weiss H: rRNA genes - their distribution and activity in plants. In Plant Cytogenetics. Edited by Małuszynska J. Katowice: Silesian University Press; 1998:75-95.

43. Weiss-Schneeweiss H, Schneeweiss GM: Karyotype diversity and evolutionary trends in angiosperms. In Plant Genome Diversity, Volume 2, Physical Structure, Behavior and Evolution of Plant Genomes. Edited by Leitch IJ, Greilhuber J, Doležel J, Wendel JF. Wien: Springer-Verlag; 2013:209-230

44. Alvarez I, Wendel JF: Ribosomal ITS sequences and plant phylogenetic inference. Mol Phylogenet Evol 2003, 29:417-434.

45. Nieto Feliner G, Rosselló JA: Better the devil you know? Guidelines for insightful utilization of nrDNA ITS in species-level evolutionary studies in plants. Mol Phylogenet Evol 2007, 44:911-919.

46. Volkov RA, Medina FJ, Zentgraf U, Hemleben V: Organization and molecular evolution of rDNA, nucleolar dominance, and nucleolus structure. Prog Bot 2004, 65:106-146.

47. Mlinarec J, Šatović Z, Malenica N, Ivančić-Baće I, Besendorfer V: Evolution of the tetraploid Anemone multifida $(2 n=32)$ and hexaploid $A$. baldensis $(2 n=48)$ (Ranunculaceae) was accompanied by rDNA loci loss and intergenomic translocation: evidence for their common genome origin. Ann Bot 2012, 110:703-712 
48. Fulneček J, Lim KY, Leitch AR, Kovarik A, Matyašek R: Evolution and structure of 5S rDNA loci in allotetraploid Nicotiana tabacum and its putative parental species. Heredity 2002, 88:19-25.

49. Gottlob-McHugh SG, Lévesque M, MacKenzie K, Olson M, Yarosh O, Johnson DA: Organization of the 5S rRNA genes in the soybean Glycine max (L.) Merrill and conservation of the $5 \mathrm{~S}$ rDNA repeat structure in higher plants. Genome 1990, 33:486-494

50. Kellogg EA, Appels R: Intraspecific and interspecific variation in 5S RNA genes are decoupled in diploid wheat relatives. Genetics 1995, 140:325-343.

51. Besendorfer V, Krajačić-Sokol I, Jelenić S, Puizina J, Mlinarec J, Sviben T, Papeš D: Two classes of 5S rDNA unit arrays of the silver fir, Abies alba Mill.: structure, localization and evolution. Theor Appl Genet 2005, 110:730-741.

52. Lepen I, Puizina J: FISH mapping of 18S-5.8S-26S rRNA genes and flourochorme banding in the triploid viviparous onion Allium $x$ cornutum Clementi ex Visiani, 1842. Acta Biol Cracov Bot 2011, 53:111-116.

53. Kotseruba V, Pistrick K, Blattner FR, Kumke K, Weiss O, Rutten T, Fuchs J, Endo T, Nasuda S, Ghukasyan A, Houben A: The evolution of the hexaploid grass Zingeria kochii (Mez) Tzvel. $(2 n=12)$ was accompanied by complex hybridization and uniparental loss of ribosomal DNA. Mol Phylogenet Evol 2010, 56:146-155.

54. Clarkson JJ, Lim KY, Kovarik A, Chase MW, Knapp S, Leitch AR: Long-term genome diploidization in allopolyploid Nicotiana section Repandae (Solanaceae). New Phytol 2005, 168:241-252.

55. Ma XF, Gustafson JP: Genome evolution of allopolyploids: a process of cytological and genetic diploidization. Cytogenet Genome Res 2005, 109:236-249.

56. Weiss-Schneeweiss H, Schneeweiss GM, Stuessy TF, Mabuchi T, Park JM, Jang CG, Sun BY: Chromosomal stasis in diploids contrasts with genome restructuring in auto- and allopolyploid taxa of Hepatica (Ranunculaceae). New Phytol 2007, 174:669-682

57. Weiss-Schneeweiss H, Tremetsberger K, Schneeweiss GM, Parker JS, Stuessy TF: Karyotype diversification and evolution in diploid and polyploid South American Hypochaeris (Asteraceae) inferred from rDNA localization and genetic fingerprint data. Ann Bot 2008, 101:909-918.

58. Hizume M: Allodiploid nature of Allium wakegi Araki revealed by genomic in situ hybridization and localization of 5S and 18S rDNAs. Jpn J Genet 1994, 69:407-415.

59. Ricroch A, Peffey EB, Baker RJ: Chromosomal location of rDNA in Allium: in situ hybridization using biotin- and fluorescein-labelled probe. Theor Appl Genet 1992, 83:413-418.

60. Lee SH, Do GS, Seo BB: Chromosomal localization of 5S rRNA gene loci and implications for relationships within the Allium complex. Chrom Res 1999, 7:89-93.

61. Do GS, Seo BB, Yamamoto M, Suzuki G, Mukai Y: Identification and chromosomal location of tandemly repeated DNA sequences in Allium cepa. Genes Genet Syst 2001, 76:53-60.

62. Saghai Maaroof MA, Soliman KM, Jorgensen RA, Allard RW: Ribosomal DNA spacer length polymorphism in barley: Mendelian inheritance, chromosomal location and population dynamics. Proc Natl Acad Sci USA 1984, 81:8014-8018.

63. Bezić N, Šamanić I, Dunkić V, Besendorfer V, Puizina J: Essential Oi composition and internal transcribed spacer (ITS) sequence variability of four south-Croatian satureja species (lamiaceae). Molecules 2009, 14:925-938

64. Hall TA: BioEdit: a user friendly biological sequence alignment editor and analysis program for Windows 95/98/NT. Nucleic Acids Symp Ser 1999, 41:95-98.

65. Higgins DG, Thompson JD, Gibson TJ: Using CLUSTAL for multiple sequence alignments. Meth Enzymol 1996, 266:383-402.

66. Tamura K, Peterson D, Peterson N, Stecher G, Nei M, Kumar S: MEGA5: molecular evolutionary genetics analysis using maximum likelihood, evolutionary distance, and maximum parsimony methods. Mol Biol Evol 2011, 28:2731-2739.

67. Librado P, Rozas J: DnaSP v5: A software for comprehensive analysis of DNA polymorphism data. Bioinformatics 2009, 25:1451-1452.

68. Ronquist F, Huelsenbeck JP: MRBAYES 3: Bayesian phylogenetic inference under mixed models. Bioinformatics 2003, 19:1572-1574.

69. Akaike H: A new look at the statistical model identification. IEEE Trans Autom Control 1974, 19:716-723.
70. Posada D: JModelTest: phylogenetic model averaging. Mol Biol Evol 2008, 25:1253-1256.

71. Swofford DL: PAUP*: Phylogenetic Analysis Using Parsimony ( ${ }^{*}$ and Other Methods), Version 4.06.10 for 32-Bit Microsoft Windows. Sunderland, MA, USA: Sinauer Associates; 2001.

72. Gerlach WL, Dyer TA: Sequence organization of the repeating units in the nucleus of wheat which contain 5S rRNA genes. Nucleic Acid Res 1980, 8:4851-4865.

73. Torres-Ruiz RA, Hemleben V: Pattern and degree of methylation in ribosomal RNA genes of Cucurbita pepo L. Plant Mol Biol 1994, 26:1167-1179.

74. Weiss-Schneeweiss H, Riha K, Jang CG, Puizina J, Scherthan H, Schweizer D: Chromosome termini of the monocot plant Othocallis siberica are maintained by telomerase, which specifically synthesizes vertebrate-type telomere sequences. Plant J 2004, 37:484-493.

doi:10.1186/1471-2229-14-24

Cite this article as: Fredotović et al:: Triparental origin of triploid onion, Allium $\times$ cornutum (Clementi ex Visiani, 1842), as evidenced by molecular, phylogenetic and cytogenetic analyses. BMC Plant Biology 2014 14:24

\section{Submit your next manuscript to BioMed Central and take full advantage of:}

- Convenient online submission

- Thorough peer review

- No space constraints or color figure charges

- Immediate publication on acceptance

- Inclusion in PubMed, CAS, Scopus and Google Scholar

- Research which is freely available for redistribution
C) Biomed Central 